\title{
Fenomena Internet Addiction Disorder Pada Gen Z
}

\section{The Phenomenon Internet Addiction Disorder of Gen Z}

\author{
Ogianto Putra*, Dinda Rakhma Fitriani
}

Fakultas IImu Komunikasi, Universitas Gunadarma

This research aims to determine and analyze the phenomenon Internet Addiction Disorder of Gen Z. The method used is a descriptive qualitative approach, in which the researcher makes observations involved, structured interviews that have been made previously with reference to aspects or indicators of existing variables. The theory used is the $\mathrm{CMC}$ (Computer Mediated Communication) theory and the Lifestyle theory. The results show that the role of social media Instagram has a huge impact on progress lifestyle of the younger generation. Instagram it's not just to post pictures and videos, but makes it easy for users to find information or anything they want. Even though Instagram has many positive impacts, for them it is possible to have many negative impacts. The negative impact of excessive use of social media can reduce the social, health and mental illness of the younger generation.

Keywords: Internet Addiction Disorder, Lifestyle, Younger

OPEN ACCESS

ISSN 2541-2841 (online)

ISSN 2302-6790 (print)

Edited by:

Poppy Febriana

Reviewed by:

Juariyah

${ }^{*}$ Correspondence:

Ogianto Putra

Ogiantoputra2@gmail.com

Received: 2 Juli 2019

Accepted: 7 Juli 2019

Published: 1 September 2019

Citation:

Putra $O$ and Fitriani DR (2019)

Fenomena Internet Addiction

Disorder Pada Gen Z.

Kanal. 8:1.

doi: 10.21070/kanal.v\%vi\%i.2593
Penelitian ini bertujuan untuk mengetahui dan menganalisis Fenomena Internet Addiction Disorder Pada Gen Z. Metode yang digunakan adalah pendekatan kualitatif deskriptif, dimana penelit i melakukan observasi terlibat, wawancara terstruktur yang telah dibuat sebelumnya dengan mengacu pada aspek - aspek atau indikator variabel yang ada. Teori yang digunakan adalahteori CMC ( Computer Mediated Communication) dan teori Gaya H idup. Hasil Penelitian menunjukan bahwa peran media sosial Instagram sangat berdampak besar bagi perkembangan gaya hidup generasi remaja. Instagram tidak hanya untuk mem posting gambar dan video, tetapi memudahkan penggunanya untuk mencari informasi atau apapun yang di inginkan.W alaupun Instagram mempunyai ba nyak dampak positif, bagi mereka tidak menutup kemungkinan banyak dampak negatif yang juga didapatkan.Dampak negatif dari pengg unaan media sosial secara berlebihan dapat mengurangi sifat sosial, kesehatan dan mental pada generasi remaja.

Keywords: Internet Addiction Disorder, Gaya Hidup, Remaja

\section{PENDAHULUAN}

Semakin banyak jumlah penggunaan internet membawa kepada konsekuensi meningkatnya kecanduan pada internet atau yang dikenal dengan istilah Internet Addiction. Kecanduan internet dapat mengakibatkan efek samping yang cukup besar pada kehidupan remaja, seperti kece- 
masan, depresi, penurunan fisik dan kesehatan mental, hubungan interpersonal, dan penurunan kinerja ${ }^{[1]}$ Hakim and Raj (2017).

Berdasarkan fenomena di atas dapat disimpulkan bahwa dengan adanya teknologi internet tidak hanya mempunyai dampak positif saja akan tetapi juga mempunyai dampak negatif yang diberikan. Adanya teknologi internet berdampak besar bagi kehidupan manusia pada era ini, manusia tidak bisa terlepas dari internet atau media sosial. Media sosial bisa berdampak buruk jika kehidupan nyata sangat bergantung pada media sosial. Saat ini semua orang tidak lagi memikirkan ruang private, tidak adanya batas antara kehidupan nyata dan kehidupan dunia maya. Fungsi media sosial telah bergeser ke arah negatif, contohnya seperti seseorang tidak segan mengumbar masalah pribadi mereka ke media sosial, memamerkan apapun ke media sosial, dan akan gelisah jika salah satu foto hanya mendapatkan like tidak banyak.

Dunia seakan-akan tidak memiliki batas ruang dan waktu, sehingga sangat mudah dijelajahi. Remaja di seluruh dunia begitu lekat dengan media sosial, mereka terus berkomunikasi lewat media sosial, bahkan pada saat makan, berjalan dan belajar. Waktu yang dihabiskan untuk media sosial seringkali lebih banyak dibandingkan dengan waktu yang dihabiskan untuk belajar atau berkumpul bersama keluarga. Meminta pendapat, menumbuhkan citra, hobi dan untuk menambah teman ${ }^{[2]}$ Mahendra (2017).

Salah satu media sosial yang menjadi sorotan adalah instagram. Menurut Ali (2017) instagram merupakan aplikasi yang berbasis foto. Pengguna bisa mengambil foto, menerapkan filter digital dan membagikannya ke berbagai layanan media sosial, termasuk milik Instagram sendiri, terdapat fitur Instagram yang sangat digandrungi masyarakat pada saat ini $^{[3]}$ Ali and Purwandi (2017).

Instagram berdiri pada tahun 2010 dan didirikan oleh dua bersahabat Kevin Systrom dan M ike Krieger. Tujuan utama dari instagram itu sendiri salah satunya yakni sebagai sarana kegemaran dari masing - masing individu yang ingin mempublikasikan kegiatan, barang, tempat atau pun dirinya sendiri ke dalam bentuk foto.

Saat ini pengguna instagram yang paling banyak adalah dari kalangan remaja. Remaja adalah kelompok masyarakat yang paling rentan mengalami kecanduan media sosial dari pada kelompok masyarakat lainnya. Setiap masyarakat kalangan remaja dan anak-anak hampir semua pasti memiliki media sosial Instagram. Jangan ngaku anak gaul kalau enggak punya account Instagram begitulah kira -kira komentar dari para remaja yang telah menjadi anggota di Instagram. Dari sekian banyaknya aplikasi media sosial yang tersedia Instagram merupakan salah satu media sosial yang paling banyak digunakan dan diminati oleh pengguna internet dan gadget, khususnya bagi remaja ${ }^{[4]}$. Nabila and Amri (2018)

Dalam kajian ilmu komunikasi, fenomena di atas dapat dikaji dengan perspektif CMC yang tertuju pada cara komputer menyalurkan dan memediasi model komunikasi face - to - fadefinisi Computer Mediated Communication yaitu proses komunikasi antara manusia melalui komputer, melibatkan orang, terletak dalam konteks tertentu, terlibat dalam proses pembentukan media untuk berbagai tujuan. Dalam prakteknya, CMC biasanya dihubungkan secara spesifik dengan komunikasi manusia maupun menggunakan komponen internet dan website ${ }^{[5]}$. Fridha and Octavianti (2016)

Pada Jaman dahulu tidak pernah terbayangkan bagaimana kita dapat melihat gambar dan film, membaca koran, atau menonton siaran televisi dari telepon genggam kita yang tidak lagi terhubung dengan kabel sehingga kita dapat melakukannya tanpa batas, kapan dan dimana saja. Hal ini tentu berdampak pada kehidupan sosial-ekkonomi, psikologis, dan gaya hidup[6] Arnus (2015).

Gaya hidup adalah pola hidup seseorang di dunia yang diekspresikan dalam aktivitas, minat, dan opininya. Gaya hidup menggambarkan "keseluruhan diri seseorang " dalam berinteraksi dengan lingkungannya. Gaya hidup menggambarkan seluruh pola seseorang dalam beraksi dan berinteraksi di dunia ${ }^{[7]}$ Kotler and Manajemen Pemasaran: Edisi Milenium (2002).

Blackwell, Miniard dan Engel ${ }^{[8]}$ Blackwell et al. (1994) menjelaskan aspek - aspek yang membentuk gaya hidup yang biasa disebut AIO, yaitu :

1. Activitties (aktivitas), meliputi apa yang dilakukan, apa yang dibeli dan bagaimana seseorang menghabiskan waktu serta uangnya.. 
2. nterest (minat), meliputi prefensi dan prioritas seseorang dalam memilih produk yang akan dibeli.

3. Opinion (opini), meliputi pandangan dan perasaan seseorang terhadap produk - produk yang ada di kehidupannya.

\section{METODE PENELITIAN}

Dalam penelitian ini subjek yang diteliti adalah generasi remaja yang mengalami Internet Addiction Disorder, pengunaan media sosial Instagram secara berlebihan atau disebut dengan kecanduan yang Addictif pada media sosial, karena dapat mempengaruhi dalam pembentukan gaya hidup generasi remaja. Strategi pendekatan penelitian yang digunakan dalam penelitian ini adalah studi kasus. Yin mendefinisikan studi kasus sebagai suatu metode dalam melakukan suatu penelitian akan fenomena yang terjadi dengan fokus pada pengalaman hidup seseorang ( real life context ), ketika terdapat gap antara fenomena dengan konteks yang ada, atau ketika menggunakan multiple source evidences. Pada umumnya, studi kasus akan menjawab satu atau lebih pertanyaan penelitian yang diawali dengan kata " how " or " why ". Data yang terkumpul pada bulan Juli 2019 hingga Agustus 2019 kemudian dianalisis dan dilakukan triangulasi ${ }^{[9]}$ Yona (2006). Menurut Moleong ${ }^{[10]}$ Moleong (2005) triangulasi adalah teknik pemeriksaan keabsahan data yang memanf aatkan sesuatu yang lain diluar data itu, untuk keperluan pengecekan atau pembanding terhadap data tersebut. Triangulasi menurut Patton ${ }^{[11]}$ Poerwandari (2005) langkah-langkah triangulasi data yaitu triangulasi data, triangulasi metodologis, dan triangulasi teori. Penelitian ini menggunakan triangulasi sumber data karena dilakukan dengan cara mencari data dari banyak sumber informan, yaitu orang yang terlibat langsung dengan objek kajian.

\section{HASIL DAN PEMBAHASAN}

Dengan menggunakan data berupa observasi dan wawancara terlibat, peneliti sudah membandingkan beberapa pendapat dari informan. Hasil yang telah diperoleh dari semua informan yaitu, Instagram sangat berdampak besar bagi perkembangan gaya hidup generasi remaja. Menurut mereka dengan adanya Instagram sangat memudahkan mereka mencari suatu informasi atau poduk yang di inginkan, walaupun Instagram mempunyai banyak dampak positif bagi mereka tidak menutup kemungkinan banyak dampak negatif yang juga didapatkan.

Dampak negatif dari adanya media sosial terutama Instagram yang sangat buruk yaitu Internet Addiction Disorder. Internet Addiction Disoder adalah pemakaian internet secara berlebihan yang ditandai dengan gejala - gejala klinis kecanduan, seperti keasyikan dengan suatu objek candu, tidak memperdulikan dampak fisik maupun psikologis pemakaian dan sebagainya. Penggunaan internet yang berlebihan tersebut, dapat dikategorikan ke dalam gangguan Internet Addiction Disorder (IAD) atau gangguan kecanduan internet, yakni meliputi segala macam hal yang berhubungan dengan internet seperti jejaring sosial, email, pornografi, judi online, game online, chatting, dan lain - lain. Adiksi terhadap internet terlihat dari intensi waktu yang digunakan seseorang untuk terpaku di depan komputer atau segala macam alat elektronik yang memiliki koneksi internet, dimana akibat banyaknya waktu yang mereka gunakan untuk online membuat mereka tidak peduli dengan kehidupan mereka yang terancam, seperti nilai yang buruk di kampus atau mungkin kehilangan pekerjaan dan bahkan meninggalkan orang orang yang disayangi ${ }^{[12]}$ Basri (2014).

Dari hasil yang telah diperoleh, beberapa informan telah mengalami gejala Internet Addiction Diorder ( IAD) karena menggunakan media sosial secara berlebihan, seperti tidur larut malam hanya karena membuka Instagram. Selain itu keseluruhan informan tidak memikirkan kesehatan $\mathrm{k}$ etika sedang membuka Instagram, contohnya melupakan waktu makan hingga merasakan penyakit maag yang dideritanya, selain itu salah satu informan pernah merasakan sakit pada matanya karena telalu lama melihat layar handphone. Pada saat ini semua orang tidak lagi memikirkan ruang private, tidak adanya batas antara kehidupan nyata dan kehidu- 
pan dunia maya. Fungsi media sosial telah bergeser kearah negatif, contohnya seperti seseorang tidak segan mengumbar masalah pribadi mereka ke media sosial dan memamerkan apapun ke media sosial terutama pada Instagram dan lebih sering menghabiskan banyak waktu di media sosial. Hingga saat ini keseluruhan informan merasa ketergantungan pada media sosial, bagi mereka tidak bermain media sosial dalam seharinya membuat mereka merasa kebingungan dan merasa hampa ketika tidak online di media sosial Instagram.

Berdasarkan pernyataan diatas mengenai Fenomena Internet Addiction Disorder pada Gen $\mathrm{Z}$ sangat berdampak buruk, karena mereka mempunyai gaya hidup yang tidak sehat secara fisik dan mental. Salah satunya generasi remaja menjadi kurang bersosi aliasi secara langsung dengan orang lain, karena mereka berpikir Instagram lebih menyenangkan untuk mereka mengeluarkan pendapat sesuka hatinya tanpa harus bertatapan langsung face to face.

\section{KESIMPULAN}

Berdasarkan hasil analisis dan pembahasan data, penulis memperoleh data dari keempat informan yaitu generasi remaja dengan proses observasi dan wawancara. Kesimpulan yang dapat diambil dari penelitian mengenai Fenomena Internet Addiction Disorder pada Gen Z. Peran media sosial Instagram sangatlah berpengaruh pada Generasi Remaja karena pengguna Instagram sangatlah banyak, dari kesimpulan yang telah peniliti lakukan generasi remaja lebih banyak menghabiskan waktunya lebih lama untuk bermain sosial media sehingga mereka lupa dengan kegiatan - kegiatan yang lebih bermanfaat daripada bermedia sosial, contohnya pola tidur yang tidak teratur dan lupa makan, bahkan beberapa informan menggunakan Instagram pada saat makan dan saat dikamar mandi. Instagram sendiri adalah media sosial wajib yang mereka akses seharinya, Dari beberapa informan memiliki rasa resah dan gelisah ketika sedang tidak mengunakan media sosial Instagram, hal yang mereka resahkan ketika tidak megakses media sosial adalah ketika mereka sedang offline yaitu perasaan hampa, dan bingung ketika tidak sedang online di media sosial.

Saran yang dapat peneliti sampaikan yaitu agar generasi remaja saat ini dap at memanfaatkan internet secara bijak, efektif, tidak berlebihan dan mengakibatkan dampak negatif yang lebih besar bagi kehidupan sehari - hari. Disarankan juga setiap pengguna internet harus lebih pintar memanfaatkan media sosial secara baik, selain itu setiap pengguna juga harus menyeimbangkan berinteraksi sosial di dunia maya dan face to face atau berkomunikasi secara langsung.

\section{UCAPAN TERIMA KASIH}

Terimakasih untuk teman-teman dan dosen di Fakultas Ilmu Komunikasi Universitas Gunadarma atas dukungannya selama ini.

\section{REFERENCES}

Ali, H. and Purwandi, L. (2017). Millenial Nusantara (Jakarta PT Gramedia Pustaka Utama).

Arnus, H. S. (2015). Computer Mediated Communications (CMC), Pola Baru Berkomunikasi. Ejournal Iain Kendari Al-Munzir 8.

Basri, A. S. (2014). Kecenderungan Internet Addiction Disorder Mahasiswa Fakultas Dakwah dan Komunikasi Ditinjau Dari Religiositas. Jurnal Dakwah XV.

Blackwell, J. E., Miniard, R. D., and Engel, P. W. (1994). Konsumer Behavior Edition 6th (Jakarta: Binarupa Aksara).

Fridha, M. and Octavianti, M. (2016). Konstruksi Makna Kencan di Situs Pencarian Jodoh Tinder (Stud Fenomenologi pada Pria Pengguna Tinder di Jakarta). Jurnal Nomosleco 2.

Hakim, S. N. and Raj, A. A. (2017). Peran Psikologi Perkembangan dalam Penumbuhan Humanitas pada Era Digital (2017): 281, In jurnal unissula, ed. and others (Semarang). Kotler, P. and Manajemen Pemasaran: Edisi Milenium (2002).
Manajemen Pemasaran: Edisi Milenium. vol. 1 (Jakarta: Prenhallindo).

Mahendra, B. (2017). Eksistensi Sosial Remaja Dalam Instagram (Sebuah Perspektif Komunikasi). Jurnal Visi Komunikasi $16,151-160$.

Moleong, L. J. (2005). Metodologi Penelitian Kualitatif (Bandung: Remaja Rosdakarya).

Nabila, F. and Amri, A. (2018). Fenomena Penggunaan Media Sosial Terhadap Gaya Hidup Remaja (Penelitian Di Desa Kepala Bandar Kecamatan Susoh Kabupaten Aceh Barat Daya). Jurnal Ilmiah Mahasiswa Fakultas Ilmu Sosial dan Ilmu Politik 3, 135-146.

Poerwandari, K. E. (2005). Pendekatan Kualitatif untuk Penelitian Perilaku Manusia (Jakarta: Lembaga Pengembangan Sarana Pengukuran dan Pendidikan Psikologi).

Yona, S. (2006). Metodologi Penyusunan Studi Kasus. Jurnal Keperawatan Indonesia 10.

Conflict of Interest Statement: The authors declare that the research was conducted in the absence of any commercial or 
financial relationships that could be construed as a potential conflict of interest.

Copyright (c) 2019 Putra and Fitriani. This is an open-access article distributed under the terms of the Creative Commons Attribution License (CC BY). The use, distribution or repro- duction in other forums is permitted, provided the original author(s) and the copyright owner(s) are credited and that the original publication in this journal is cited, in accordance with accepted academic practice. No use, distribution or reproduction is permitted which does not comply with these terms. 